\title{
Improved detection of Rhodococcus coprophilus with a new quantitative PCR assay
}

\author{
Melanie Wicki • Adrian Auckenthaler • \\ Richard Felleisen • Marianne Liniger • \\ Caroline Loutre • Isabel Niederhauser • \\ Marcel Tanner • Andreas Baumgartner
}

Received: 9 August 2011 /Revised: 30 December 2011 / Accepted: 2 January 2012 / Published online: 26 January 2012

(C) Springer-Verlag 2012

\begin{abstract}
Agricultural practices, such as spreading liquid manure or the utilisation of land as animal pastures, can result in faecal contamination of water resources. Rhodococcus coprophilus is used in microbial source tracking to indicate animal faecal contamination in water. Methods previously described for detecting of $R$. coprophilus in water were neither sensitive nor specific. Therefore, the aim of this study was to design and validate a new quantitative polymerase chain reaction (qPCR) to improve the detection of $R$. coprophilus in water. The new PCR assay was based on the $R$. coprophilus 16S rRNA gene. The validation showed that the new approach was specific and sensitive for deoxyribunucleic acid from target host species.
\end{abstract}

Electronic supplementary material The online version of this article (doi:10.1007/s00253-012-3888-4) contains supplementary material, which is available to authorized users.

M. Wicki · R. Felleisen · M. Liniger $\cdot$ I. Niederhauser •

A. Baumgartner

Federal Office of Public Health,

3003 Bern, Switzerland

M. Wicki $\cdot$ M. Tanner

Swiss Tropical and Public Health Institute,

4002 Basel, Switzerland

M. Wicki $(\bowtie) \cdot$ M. Tanner

University of Basel,

4000 Basel, Switzerland

e-mail: Melanie.Wicki@gmx.ch

A. Auckenthaler

Office of Environmental Protection and Energy,

Basel-Landschaft,

4410 Liestal, Switzerland

C. Loutre

University of Lausanne,

1015 Lausanne, Switzerland
Compared with other PCR assays tested in this study, the detection limit of the new qPCR was between 1 and $3 \log$ lower. The method, including a filtration step, was further validated and successfully used in a field investigation in Switzerland. Our work demonstrated that the new detection method is sensitive and robust to detect $R$. coprophilus in surface and spring water. Compared with PCR assays that are available in the literature or to the culture-dependent method, the new molecular approach improves the detection of $R$. coprophilus.

Keywords Contamination $\cdot$ LightCycler $\cdot$ Sewage . Validation · Water quality

\section{Introduction}

Agricultural practices, such as spreading liquid manure or the use of land as animal pastures, can result in faecal contamination of water resources. In order to maintain high water quality, water resources should be protected from faecal pollution by the detection and remediation of faecal input sites. Different microbial source tracking (MST) approaches have been proposed in order to detect the source of faecal contamination (Meays et al. 2004; Savichtcheva and Okabe 2006; Scott et al. 2002; Sinton et al. 1998). Rhodococcus coprophilus, first described and classified by Rowbotham and Cross (1977a, b), was one of the first bacteria used in MST. It was shown that this actinomycete is present at high levels in faeces of different animal species such as cattle, sheep, pigs, horses, ducks, geese, and hens (Mara and Oragui 1981; Savill et al. 2001). The absence in human faecal specimens qualifies $R$. coprophilus as a good indicator for animal pollution, but its use is limited by inadequate detection methods. The selectivity of M3 agar 
developed by Rowbotham and Cross $(1977 \mathrm{a}, \mathrm{b})$ was found to be inadequate for the detection of $R$. coprophilus in sewage. Consequently, the M3 agar was modified by adding naladixic acid and sodium azide as supplements to increase selectivity, but complete inhibition of contaminating bacteria was still not achieved (Mara and Oragui 1981). The major drawback of the detection procedure on this modified M3 (MM3) agar, however, was the long incubation time of 14-21 days (Jagals et al. 1995; Mara and Oragui 1981; Oragui and Mara 1983). To overcome these restrictions, a conventional as well as a TaqMan quantitative polymerase chain reaction (qPCR) assay were developed by the group of Savill et al. (2001). Both PCR assays targeted the 16S rRNA gene amplifying a 443 bp sequence. Our evaluation of these approaches did not reveal any satisfactory result because the PCR assays were neither specific nor sensitive. Therefore, the aim of this study was to design a new LightCycler qPCR assay with high sensitivity, specificity, repeatability and to compare the novel procedure with the previously published PCR assays.

\section{Materials and methods}

\section{Isolation of presumptive colonies}

One liquid manure sample from a farm with 20-30 cows was analysed with a culture-based detection method. A serial dilution was performed in peptone saline solution and $100 \mu \mathrm{l}$ of each dilution was plated in duplicate on modified MM3 agar (Mara and Oragui 1983). The agar was prepared by dissolving $0.466 \mathrm{~g}$ of $\mathrm{KH}_{2} \mathrm{PO}_{4}, 0.732 \mathrm{~g}$ of $\mathrm{Na}_{2} \mathrm{HPO}_{4}, 0.1 \mathrm{~g}$ of $\mathrm{KNO}_{3}, 0.29 \mathrm{~g}$ of $\mathrm{NaCl}, 0.1 \mathrm{~g}$ of $\mathrm{MgSO}_{4} \cdot 7 \mathrm{H}_{2} \mathrm{O}, 0.02 \mathrm{~g}$ of $\mathrm{CaCO}_{3}, 0.2 \mathrm{~g}$ of propionic acid sodium salt, $200 \mu \mathrm{l}$ of $\mathrm{FeSO}_{4} \cdot 7 \mathrm{H}_{2} \mathrm{O}\left(1 \mathrm{mg} \mathrm{ml}^{-1}\right), 180 \mu \mathrm{l}$ of $\mathrm{ZnSO}_{4} \cdot 7 \mathrm{H}_{2} \mathrm{O}\left(1 \mathrm{mg} \mathrm{ml}{ }^{-1}\right), 20 \mu \mathrm{l}$ of $\mathrm{MnSO}_{4} \cdot 4 \mathrm{H}_{2} \mathrm{O}$ $\left(1 \mathrm{mg} \mathrm{ml}^{-1}\right), 200 \mu \mathrm{l}$ of nalidixic acid $\left(25 \mathrm{mg} \mathrm{ml}^{-1}\right), 18 \mathrm{~g}$ of granulated Agar-agar (Merck, Switzerland) and $3.5 \mathrm{mg}$ of sodium azide in 11 of distilled water. The agar was mixed under heating. After sterilisation by autoclaving at $121{ }^{\circ} \mathrm{C}$ for $15 \mathrm{~min}$ and cooling to $50{ }^{\circ} \mathrm{C}, 1 \mathrm{ml}$ of amphotericin B $\left(2.5 \mathrm{mg} \mathrm{ml}^{-1}\right)$ and $1 \mathrm{ml}$ of thiamine hydrochloride $\left(4 \mathrm{mg} \mathrm{ml}^{-1}\right)$ were added. With a final $\mathrm{pH}$ of $7.0 \pm 0.1$, the liquid medium $(30 \mathrm{ml})$ was poured into Petri dishes $(90-\mathrm{mm}$ diametre). Inoculated plates were incubated at $30^{\circ} \mathrm{C}$ for 14 days followed by a 7-day exposure to sunlight at room temperature. All presumptive, reddish colonies were inoculated on trypticase soy broth (TSB) including $14 \mathrm{~g}$ agar prepared as recommended by the German Collection of Microorganisms and Cell Cultures (http://www.dsmz.de/microorganisms/medium/pdf/DSMZ_Me dium535.pdf) and incubated at $30{ }^{\circ} \mathrm{C}$ for 4 days for further confirmation. Based on colony morphology observed on TSB agar, isolates were classified into two groups (typical or atypical). Isolates which grew as dry, reddish and irregular colonies with a bumpy surface were considered to be typical. The Microbank $^{\circledR}$ preservation system (Pro-lab Diagnostics) was used to store all isolates at $-70{ }^{\circ} \mathrm{C}$.

\section{Isolation of DNA}

Deoxyribunucleic acid (DNA) was extracted from all samples using the DNeasy Blood and tissue kit (Qiagen, Switzerland), following the protocol pretreatment for Gram-positive bacteria. All samples were eluted in buffer AE (provided in the kit) in a final volume of $200 \mu \mathrm{l}$.

\section{Characterisation of strains}

The 16S rRNA gene of the reference strains $R$. coprophilus DSM 43347, DSM 43591, DSM 44751 and DSM 43447 and seven typical and six atypical strains isolated from liquid manure were characterised by $16 \mathrm{~S}$ rRNA gen $(1,500 \mathrm{bp})$ sequencing. The DNA was extracted as described under 'Isolation of DNA' before sequencing by the Institut für Medizinische und Molekulare Diagnostik (IMD; Switzerland).

\section{LightCycler PCR}

\section{Development of the new PCR assay}

For primer design, the publicly available database [National Center for Biotechnology Information (NCBI)] was searched for $R$. coprophilus sequences. Multiple sequence alignments were performed with clustalw (http://www.ebi. ac.uk/Tools/clustalw2/) and included all 16S rRNA sequences of $R$. coprophilus as well as sequences obtained from newly isolated and sequenced strains (for details, see 'Isolation of presumptive colonies' and 'Characterisation of strains'). Five primers were designed on the 16S rRNA gene sequence (accession no. X80626). The chosen primers were placed in regions identified as being conserved among the $R$. coprophilus strains. Four primers were designed on a sequence of the gene for the DNA gyrase B subunit (accession no. AB014271). For primer design, the software Genefisher (http://bibiserv.techfak.uni-bielefeld.de/genefisher2/) was used. Specificity and sensitivity were initially estimated in silico by nucleotide blast searches (NCBI). Thirteen different primer combinations, including previously described primers, RhodoF and RhodoR (see Table 1), were used to analyse serial dilutions of two $R$. coprophilus reference strains (DSM 43347 and DSM 43591). Nine primer combinations targeted the sequence of the 16S rRNA gene, and four combinations targeted the sequence on the gene for the DNA gyrase B subunit. Additional information on primer positions and amplicon sizes are available as supplementary information (online resource 1). DNA from $1 \mathrm{ml}$ samples of serial dilutions was extracted as described under 'Isolation 
Table 1 Primer pairs and probes used in the study

\begin{tabular}{|c|c|c|c|c|c|}
\hline PCR assay & Target gene & $\begin{array}{l}\text { GenBank accession } \\
\text { number }\end{array}$ & Labelling and position & Primer and probe sequences & Reference \\
\hline \multirow[t]{3}{*}{$\begin{array}{l}\text { LightCycler } \\
\text { PCR }\end{array}$} & \multirow[t]{3}{*}{ 16S rRNA gene } & \multirow[t]{3}{*}{ X80626 } & $\begin{array}{l}\text { CL1.1 F: } 68-86 \\
\text { CL9 R: } 451-470\end{array}$ & $\begin{array}{l}\text { 5'-TGG GCG GAT TAG TGG CGA A-3' } \\
5^{\prime} \text {-GTT AGC CGG TGC TTC TTC TG-3' }\end{array}$ & \multirow[t]{3}{*}{ This study } \\
\hline & & & RC_3'FL: 140-166 & $\begin{array}{l}\text { 5'-ACT GGG TCT AAT ACC GGA TAT } \\
\text { GAC CAT-FL-3' }\end{array}$ & \\
\hline & & & RC_5'LC640: 170-199 & $\begin{array}{l}\text { 5'-LC640-ATG CAT GTC CTG TGG TGG } \\
\text { AAA GGT TTA CTG-PH-3' }\end{array}$ & \\
\hline \multirow[t]{3}{*}{ TaqMan PCR } & \multirow[t]{3}{*}{ 16S rRNA gene } & \multirow[t]{3}{*}{ X80626 } & RhodoF: 143-166 & $\begin{array}{l}\text { 5'-GGG TCT AAT ACC GGA TAT GAC } \\
\text { CAT-3' }\end{array}$ & \multirow[t]{3}{*}{ Savill et al. 2001} \\
\hline & & & RhodoR: 561-585 & $\begin{array}{l}\text { 5'-GCA GTT GAG CTG CGG GAT TTC } \\
\text { ACA C-3' }\end{array}$ & \\
\hline & & & RhodoPr: 170-199 & $\begin{array}{l}\text { 6FAM-ATG CAT GTC CTG TGG TGG A } \\
\text { AA GGT TTA CTG-TAMRA }\end{array}$ & \\
\hline \multirow[t]{2}{*}{$\begin{array}{l}\text { Conventional } \\
\text { PCR }\end{array}$} & \multirow[t]{2}{*}{ 16S rRNA gene } & \multirow[t]{2}{*}{ X80626 } & RhodoF: 143-166 & $\begin{array}{l}\text { 5'-GGG TCT AAT ACC GGA TAT GAC } \\
\text { CAT-3' }\end{array}$ & \multirow[t]{2}{*}{ Savill et al. 2001} \\
\hline & & & RhodoR: 561-585 & $\begin{array}{l}\text { 5'-GCA GTT GAG CTG CGG GAT TTC } \\
\text { ACA C-3' }\end{array}$ & \\
\hline
\end{tabular}

of DNA'. A conventional PCR approach was performed using a LightCycler 1.1 Instrument (Roche) in a $20 \mu \mathrm{l}$ reaction volume consisting of the following reagents and concentrations: $4 \mu \mathrm{l}$ LightCycler FastStart DNA Master ${ }^{\text {Plus }}$ HybProbe $(5 \times), 1 \mu \mathrm{l}$ of each primer $\left(10 \mathrm{pmol} \mu \mathrm{l}^{-1}\right), 9 \mu \mathrm{l}$ $\mathrm{H}_{2} \mathrm{O}$ and $5 \mu \mathrm{l}$ template DNA. The amplification protocol was $95^{\circ} \mathrm{C}$ for $10 \mathrm{~min}$ followed by 45 cycles of amplification $\left(95^{\circ} \mathrm{C}\right.$ for $15 \mathrm{~s}, 60^{\circ} \mathrm{C}$ for $20 \mathrm{~s}$ and $72{ }^{\circ} \mathrm{C}$ for $25 \mathrm{~s}$ ). The PCR products were loaded on a $2 \%$ agarose gel. On every gel, $500 \mathrm{ng} \mathrm{well}{ }^{-1}$ of a 100-bp ladder (New England biolabs) was run as a molecular size marker. After electrophoresis, gels were stained in a solution of ethidium bromide at a concentration of $1.1 \mathrm{mg} \mathrm{ml}^{-1}$ for $20 \mathrm{~min}$. The DNA was visualised under ultraviolet illumination $(320 \mathrm{~nm})$ using the AlphaImager software version 4.1.0. Primer combinations with a low detection limit using serial dilutions of the $R$. coprophilus strains DSM 43347 and 43591 were further used to test specificity with two $R$. coprophilus strains and three Dietzia sp. strains isolates from liquid manure.

Hybridisation probes (RC_3'FL and RC_5'LC640) were designed in conserved regions from the 16S rRNA gene sequence of $R$. coprophilus. For quantification with the LightCycler, two probes are used. Each Probe is labelled with only one dye. As soon as both probes bind to the target sequence, fluorescence resonance energy transfer occurs. The TaqMan PCR is based on only one probe: the fluorophore on the $5^{\prime}$-end is suppressed by a quencher on the $3^{\prime}$ end until the probe is degraded by the Taq polymerase. The sequence of the LightCycler probe RC 5'LC640 was identical with that of the TaqMan probe RhodoPr. The combinations of forward primer CL1.1 F, reverse primer CL9R and the probes RC_3'FL and RC_5'LC640 were further validated. The sequences of primers and probes are shown in
Table 1 . The PCR procedure described above was slightly modified to a qPCR setup: $0.8 \mu \mathrm{l}$ of each probe (RC_3'FL and

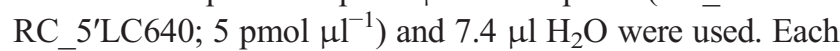
run contained a positive (DSM 43347 strain) and a negative $\left(\mathrm{H}_{2} \mathrm{O}\right)$ control, which were extracted together with the analysed samples. Moreover, DNA from a serial dilution of $R$. coprophilus DSM 43591 or DSM 43347 over five logs was included in each PCR run to generate a standard curve used to control the efficiency and to quantify the PCR product. The data analysis was performed using the second derivative maximum method of the LightCycler software (version 4.1.1.21). Samples with quantification cycle $(\mathrm{Cq})<40$ were counted as positive (Bustin et al. 2009).

\section{LightCycler PCR validation}

DNA from $R$. coprophilus reference strains (DSM 43347, DSM 43591 and DSM 44751), typical as well as atypical isolates, and other species of Rhodococcus including Rhodococcus fascians (DSM 43985), Rhodococcus rhodochrous (DSM 43986) and Rhodococcus jostii (DSM 8354) were used to validate the LightCycler PCR assay. The strains were grown on TSB agar plates for 4 days at $30{ }^{\circ} \mathrm{C}$. Cells were suspended in $10 \mathrm{ml}$ phosphate buffered saline (PBS) solution containing $2 \%$ bovine serum albumin (BSA) to reach a high density corresponding with a McFarland 2-4 standard. The tubes were kept at room temperature for at least $1 \mathrm{~h}$ to obtain a homogeneous solution with loose, single cells. Five $\mathrm{ml}$ of the suspension was transferred to a new glass vial and vortexed. Serial dilutions of strains were performed in PBS solution containing $2 \% \mathrm{BSA}$ and the concentration of the suspension was determined by plate counts on TSB agar. Of each dilution, $1 \mathrm{ml}$ was extracted as described under 'Isolation of DNA'. The 
validation was based on a guideline from the Swiss Accreditation Service (Anon. 2006).

Sensitivity refers to how often the assay returns a positive result when a target is present and specificity refers to how often it is negative in the absence of the target. Both values were determined by analysis of all presumptive colonies isolated from one liquid manure sample. Typical (7) and atypical (28) isolates were analysed. In addition, human and animal wastewaters were analysed (as described below under under 'Samples of human and animal origin') containing a wide range of bacterial species originating from the intestinal tract. Specificity was further tested with cultures of other species of Rhodococcus including R. fascians (DSM 43985), R. rhodochrous (DSM 43986) and $R$. jostii (DSM 8354). Repeatability was determined with a sample containing $2 \times 10^{3} \mathrm{CFU} \mathrm{ml}^{-1}$ of $R$. coprophilus (DSM 43347) measured in ten separate runs on the LightCycler Instrument 1.1. The detection limit of the LightCycler PCR assay was determined using preamplified DNA of the strain DSM 43347. The PCR product was purified and DNA concentration (ng $\mu \mathrm{l}^{-1}$ ) was measured on the NanoDrop ND1000 spectrophotometer and genome equivalents were determined. A serial dilution of estimated genome copies from $1 \times 10^{-2}$ to $1 \times 10^{5}$ copy $\mu \mathrm{l}^{-1}$ was analysed. As it is not known, how many copies of the 16S rRNA gene sequence are contained in one $R$. coprophilus cell, the detection limit in cells per initial volume was determined. Serial dilutions of three different $R$. coprophilus reference strains were used. DNA was analysed from serial dilutions containing $2.1 \times 10^{0}$ to $2.1 \times 10^{8} \mathrm{CFU} \mathrm{ml}^{-1}$ for strain DSM $43347,7.5 \times 10^{-1}$ to $7.5 \times 10^{7} \mathrm{CFU} \mathrm{ml}{ }^{-1}$ for strains DSM 43591 and $2.9 \times 10^{0}$ to $7.5 \times 10^{8} \mathrm{CFU} \mathrm{ml}{ }^{-1}$ for strain DSM 44751. The amplification was repeated in several (>ten times) runs to determine whether the results were repeatable. To determine the detection limit in environmental samples, 30 surface water samples and 22 spring water samples were spiked with $R$. coprophilus (10 CFU ml ${ }^{-1}$ ).

DNA from a serial dilution of DSM 43347 strain $\left(1.7 \times 10^{4}\right.$ to $1.7 \times 10^{8} \mathrm{CFU} \mathrm{ml}^{-1}$ ) was analysed in pairs for the determination of the recovery rate. For quantification, DNA from a serial dilution of the DSM 43591 strain was used as described under 'Quantification'.

In addition, the recovery rate of the method including a filtration and resuspension step was evaluated. Seven samples with $9 \mathrm{ml}$ of human wastewater were prepared and spiked with $1 \mathrm{ml}$ of each dilution from a serial dilution containing $1.7 \times 10^{2}$ to $1.7 \times 10^{8} \mathrm{CFU} \mathrm{m}{ }^{-1}$ of $R$. coprophilus DSM 43347. These samples were filtered through a Microsart $\mathrm{CN}$ filter with $0.45 \mu \mathrm{m}$ pore size (Sartorius). Subsequently, the filter was immersed in $5 \mathrm{ml}$ of elution buffer $[6 \mathrm{ml}$ Tween 80, 2 g Lab-lemco (Oxoid), 5.844 g NaCl, 200 ml dd $\mathrm{H}_{2} \mathrm{O}$; Mendez et al. 2004] and cells were resuspended by sonication at $25{ }^{\circ} \mathrm{C}$ for $4 \mathrm{~min}$. After centrifugation, DNA was extracted and analysed with the LightCycler PCR assay as described above. DNA was extracted from a serial dilution $\left(7.5 \times 10^{1}\right.$ to $\left.7.5 \times 10^{6} \mathrm{CFU} \mathrm{ml}^{-1}\right)$ of $R$. coprophilus DSM 43591 to generate the standard curve for quantification of spiked samples and to determine the recovery rate.

\section{Comparison of three different PCR assays}

The LightCycler PCR assay was compared to two assays that were based on primers and probes that are available from the literature. The primer sequences, target genes and their accession numbers are shown in Table 1. DNA from all samples used for comparison was extracted as described under 'Isolation of DNA'. The TaqMan PCR was performed as described by Savill et al. (2001). Samples were amplified during 50 cycles and results with $\mathrm{Cq}<40$ were counted as positive. For the conventional PCR assay, DNA was amplified using the TaqMan PCR assay. The PCR products of the TaqMan run were analysed by means of gel electrophoresis as described above.

In order to compare the three PCR assays, the same DNA was amplified as described above for the determination of the detection limit for the LightCycler PCR. For further comparison, presumptive isolates, including typical and atypical isolates, from liquid manure and human and animal wastewater were analysed.

\section{Samples of human and animal origin}

Human and animal wastewater samples were analysed in order to further validate the LightCycler PCR assay and in order to compare the three assays. Human wastewater samples were collected from the influent at ten different Swiss treatment plants that each processed sewage from more than 100,000 inhabitants. Five wastewater samples from two big slaughterhouses were analysed. Slaughterhouses provided wastewater from cows, calves, bulls and pigs. In addition, two liquid manure samples from two Swiss farms having 20-30 cows were analysed. Liquid manure samples were diluted 1:100 in peptone saline solution ( $1 \mathrm{~g}$ peptone, $8.5 \mathrm{~g}$ $\mathrm{NaCl}, 1000 \mathrm{ml} \mathrm{dd} \mathrm{H}_{2} \mathrm{O}$ ).

From each sample with human or animal origin $10 \mathrm{ml}$ was filtered through a Microsart CN filter with $0.45 \mu \mathrm{m}$ pore size (Sartorius) followed by a washing step with $9 \mathrm{ml}$ peptone saline solution. Subsequently, the filter was transferred into a glass vial with a height of $10 \mathrm{~cm}$ and $12 \mathrm{~mm}$ in diameter containing $5 \mathrm{ml}$ elution buffer [ $6 \mathrm{ml}$ Tween $80,2 \mathrm{~g}$ Lab-lemco (Oxoid), $5.844 \mathrm{~g} \mathrm{NaCl}, 200 \mathrm{ml} \mathrm{dd} \mathrm{H}_{2} \mathrm{O}$; Mendez et al. 2004]. Bacterial cells were resuspended by sonication at $25{ }^{\circ} \mathrm{C}$ for $4 \mathrm{~min}$. The suspension was transferred into a $15 \mathrm{ml}$ polypropylene tube followed by centrifugation for 10 min at $6,000 \times g$. The pellet was frozen at $-70{ }^{\circ} \mathrm{C}$ prior to DNA extraction. Finally, DNA was extracted (see 'Isolation of 
DNA') and analysed with the three PCR assays as described above. As an inhibition control, another $10 \mathrm{ml}$ from each sample was spiked with $1 \mathrm{ml}$ of a solution containing $R$. coprophilus (DSM 43347) at a density corresponding with a McFarland 2 standard. Peptone saline solution was used as the negative control.

\section{Surface and spring water samples}

From April to September 2009, 28 spring water samples and 30 surface water samples were analysed for the validation of the PCR assays under natural conditions. Samples were collected from three springs and three different streams located in the northwestern part of Switzerland. Spring water (1 l ) and surface water $(500 \mathrm{ml})$ were filtered through $0.2 \mu \mathrm{m}$ PVP-free GTTP membranes (Millipore) and the bacteria were resuspended in $5 \mathrm{ml}$ Bennett's broth as previously described (Long et al. 2003). One ml per sample was used for DNA extraction (see 'Isolation of DNA'). After centrifugation, pellets were stored at $-70{ }^{\circ} \mathrm{C}$ before further extraction and amplification. As a positive control, an additional surface water sample was taken downstream of the effluent of the treatment plant on every day of sampling and was spiked with $R$. coprophilus (DSM 43347). Sterile water $(100 \mathrm{ml})$ was used as the negative control. Positive and negative controls were treated in the same way as the samples.

\section{Quantification}

In order to quantify the concentration of $R$. coprophilus in water samples, DNA from a serial dilution of $7.5 \times 10^{1}$ to $7.5 \times 10^{6} \mathrm{CFU} \mathrm{m} l^{-1}$ of $R$. coprophilus DSM 43591 was extracted as described under 'Isolation of DNA' and used to generate the standard curve. Dilutions of the DNA were stored at $-20{ }^{\circ} \mathrm{C}$. The concentration $\left(\mathrm{CFU} \mathrm{ml} \mathrm{m}^{-1}\right.$ ) of the serial dilution was determined by plate count on TSB agar. Concentrations of environmental samples are therefore given in calibrator CFU equivalents $\mathrm{ml}^{-1}$ throughout the manuscript.

\section{Analysis}

Statistical tests were performed with the software package, SPSS 13.0.

\section{Results}

Confirmation of presumptive colonies

From the liquid manure sample grown on modified MM3 agar, 35 presumptive $R$. coprophilus colonies with reddish pigmentation were selected. All colonies were very small in diameter and therefore the only criterion taken into consideration for selection was a reddish pigmentation. After inoculation on TSB agar, these presumptive colonies were classified into seven (20\%) typical and $28(80 \%)$ atypical colonies. The concentration of typical $R$. coprophilus colonies in the liquid manure sample was $8 \times 10^{6} \mathrm{CFU} \mathrm{ml}^{-1}$.

Sequencing results of the 16S rRNA gene showed that three sequences of the reference strains (DSM 43347, DSM 44751 and DSM 43591) had high similarity (99-99.9\% identity) with a $R$. coprophilus sequence from NCBI database (accession no. X80626.1) sequence. However, the 16S rRNA gene sequence from DSM 43591 strain showed additional similarity with Rhodococcus zopfii (accession no. AF191343.1). The strain showed an identity of $99 \%$ to both sequences (accession nos. X80626.1 and AF191343.1). Based on our classification into typical and atypical strains, we would have classified the fourth reference strain DSM 43447 as atypical based on its colony morphology. The sequencing of this strain showed high similarity ( $99.6 \%$ identity) to the Rhodococcus yunnanesis sequence (accession no. AY602219.2) and could not be confirmed as being R. coprophilus. The sequencing of strains from liquid manure confirmed our classification into typical and atypical isolates. Sequences of the seven typical isolates were highly similar (99-99.9\% identity) to $R$. coprophilus (accession no. X80626.1) and sequences of the six atypical isolates showed high identity with Dietzia sp. The atypical isolates from liquid manure identified as Dietzia sp. produced false positive results on selective modified MM3 agar plates. Rhodococcus and Dietzia belong to the order actinomycetales and to different families (nocardiaceae and dietziaceae).

Design and validation of the new $R$. coprophilus PCR assay

From nine different combinations targeting the 16S rRNA gene and the four combinations targeting the sequence on the gene for DNA gyrase B subunit, only the described primer pair (CL1.1 F and CL9R) was specific (no false positives) after combination with the hybridisation probes (RC_3'FL and RC_5'LC640; Table 1). The primer and probes were therefore selected for further validation. In silico analyses by nucleotide blast search showed that the new LightCycler PCR assay is specific and sensitive for the target sequence of $R$. coprophilus. While all seven typical isolates gave positive signals using the LightCycler PCR assay, no amplification was observed with DNA from any of the 28 atypical isolates. In addition, the assay did not detect other species of Rhodococcus including $R$. fascians (DSM 43985), $R$. rhodochrous (DSM 43986) and $R$. jostii (DSM 8354). Therefore, both sensitivity and specificity of the LightCycler PCR assay were high (100\%). High specificity was also shown with the analysis of human wastewater representing a mixture of microorganisms naturally present 
in faeces, where nine out of ten human wastewater samples were negative.

The sensitivity was slightly lower in samples of animal origin. From seven analysed samples, five were positive. The repeatability was $0.2(\mathrm{Cq})$ and consistent with the standard deviation of ten repeated measurements. The detection limit of the PCR assay was five genome copies per reaction. In order to give information about the lowest initial concentration which still can be detected in environmental samples using the new LightCycler method, the detection limit was determined using pure cultures of three reference strains. The values ranged between 2.1 and 29 calibrator CFU equivalents $\mathrm{ml}^{-1}$ (Table 2). The detection limit in environmental samples was 10 calibrator CFU equivalents $\mathrm{ml}^{-1}$. The values shown in Table 2 represent results of one experiment. The repeated analysis of the same samples showed repeatability of the LightCyler PCR assay with equivalent $\mathrm{Cq}$ values. The efficiency of the assay in all performed runs was between 1.98 and 1.79 .
The median recovery rate of the pure culture of $R$. coprophilus was $132 \%(n=5 ; 71.2-262 \%)$ and $70.6 \%(n=5$; $24.1-165 \%$ ) in human wastewater.

\section{Comparison of different PCR assays}

Analysis of pure bacterial cell cultures revealed differences in the detection limits of the three different PCR assays (Table 2). The detection limits of the TaqMan PCR assay (between $2.1 \times 10^{3}$ and $7.5 \times 10^{4}$ calibrator CFU equivalents $\mathrm{ml}^{-1}$ ) and the conventional PCR assays (between $2.1 \times 10^{2}$ and $7.5 \times 10^{2}$ calibrator $\mathrm{CFU}$ equivalents $\mathrm{ml}^{-1}$ ) were higher in comparison with the LightCycler PCR assay (2.1 and $29 \mathrm{CFU} \mathrm{ml}^{-1}$ ). Strong distinctions were observed in $\mathrm{Cq}$ values of the two qPCR assays. A Wilcoxon signed rank test was performed and a significant difference $(p<0.01)$ was observed between $\mathrm{Cq}$ values of the two qPCR assays. As shown in Table 2, differences between $\mathrm{Cq}$ values were higher when DNA from $R$.
Table 2 Detection limit of the LightCycler PCR, the TaqMan $\mathrm{PCR}$ and the conventional PCR assays
Data presented represent a single experiment

n.a. No amplification

${ }^{a_{+}}$visible band, - no band detected

${ }^{\mathrm{b}} \mathrm{Cq}$ above detection limit

\begin{tabular}{|c|c|c|c|c|c|c|}
\hline \multirow[t]{2}{*}{ Strain } & \multirow[t]{2}{*}{$\mathrm{CFU} \mathrm{ml} \mathrm{m}^{-1}$} & \multicolumn{2}{|c|}{ LightCycler PCR } & \multicolumn{2}{|c|}{ TaqMan PCR } & \multirow{2}{*}{$\begin{array}{l}\text { Conventional PCR } \\
\text { Band }^{\mathrm{a}}\end{array}$} \\
\hline & & $(\mathrm{Cq})$ & Efficiency & $(\mathrm{Cq})$ & Efficiency & \\
\hline \multirow[t]{9}{*}{ DSM 43347} & $2.1 \times 10^{8}$ & 11.73 & \multirow[t]{9}{*}{$100 \%$} & 19.06 & \multirow[t]{9}{*}{$76 \%$} & + \\
\hline & $2.1 \times 10^{7}$ & 15.00 & & 20.90 & & + \\
\hline & $2.1 \times 10^{6}$ & 17.48 & & 23.71 & & + \\
\hline & $2.1 \times 10^{5}$ & 20.70 & & 27.60 & & + \\
\hline & $2.1 \times 10^{4}$ & 24.05 & & 32.71 & & + \\
\hline & $2.1 \times 10^{3}$ & 27.42 & & 35.84 & & + \\
\hline & $2.1 \times 10^{2}$ & 32.64 & & $(41.53)^{b}$ & & + \\
\hline & $2.1 \times 10^{1}$ & 33.82 & & $(47.11)^{\mathrm{b}}$ & & - \\
\hline & $2.1 \times 10^{0}$ & 37.09 & & n.a. & & - \\
\hline \multirow[t]{9}{*}{ DSM 43591} & $7.5 \times 10^{7}$ & 15.71 & \multirow[t]{9}{*}{$100 \%$} & n.a. & \multirow[t]{9}{*}{$80 \%$} & + \\
\hline & $7.5 \times 10^{6}$ & 18.56 & & 32.20 & & + \\
\hline & $7.5 \times 10^{5}$ & 20.96 & & 34.02 & & + \\
\hline & $7.5 \times 10^{4}$ & 24.17 & & 38.13 & & + \\
\hline & $7.5 \times 10^{3}$ & 28.46 & & $(43.07)^{\mathrm{b}}$ & & + \\
\hline & $7.5 \times 10^{2}$ & 31.44 & & $(47.36)^{b}$ & & + \\
\hline & $7.5 \times 10^{1}$ & 35.47 & & n.a. & & - \\
\hline & $7.5 \times 10^{0}$ & 36.22 & & n.a. & & - \\
\hline & $7.5 \times 10^{-1}$ & n.a. & & n.a. & & - \\
\hline \multirow[t]{9}{*}{ DSM 44751} & $2.9 \times 10^{8}$ & 12.41 & \multirow[t]{9}{*}{$98 \%$} & 22.94 & \multirow[t]{9}{*}{$75 \%$} & + \\
\hline & $2.9 \times 10^{7}$ & 15.41 & & n.a. & & + \\
\hline & $2.9 \times 10^{6}$ & 18.14 & & 28.42 & & + \\
\hline & $2.9 \times 10^{5}$ & 21.24 & & 34.0 & & + \\
\hline & $2.9 \times 10^{4}$ & 24.91 & & 37.58 & & + \\
\hline & $2.9 \times 10^{3}$ & 29.74 & & $(44.61)^{b}$ & & + \\
\hline & $2.9 \times 10^{2}$ & 32.01 & & $(45.80)^{b}$ & & + \\
\hline & $2.9 \times 10^{1}$ & 34.54 & & n.a. & & - \\
\hline & $2.9 \times 10^{0}$ & n.a. & & n.a. & & - \\
\hline
\end{tabular}


coprophilus DSM 43591 or DSM 44751 was amplified than after amplification of DNA from strain DSM 43347.

While both sensitivity and specificity of the LightCycler PCR assay were high, similar estimations were more difficult to establish for the other two assays. In Table 3, the findings for typical and atypical isolates are shown and represent the data of a single experiment. While amplifications with the LightCycler were repeatable $(n=10, r=0.21)$, results were inconsistent with the two other assays. The repeatability of the TaqMan assay was $17.92(n=4)$. Using the TaqMan PCR assay the results differed from one run to another. Only three to five of seven typical isolates could be amplified, and from the 28 atypical isolates, two to four strains were detected. As shown in Table 3, some typical strains could not be amplified using the TaqMan PCR and were confirmed to be $R$. coprophilus through sequencing. In addition, strains with high sequence identity to Dietzia sp. produced false positive results in the TaqMan PCR assay.

\section{R. coprophilus in samples of human and animal origin}

As shown in Table 4, $R$. coprophilus was detected with the two qPCR assays in one of ten (10\%) human wastewater samples and twice (20\%) with the conventional PCR assay. The concentration quantified by the qPCR on the LightCycler was $4.3 \times 10^{3} \mathrm{CFU} \mathrm{ml}^{-1}$. All spiked human wastewater samples used as positive controls were positive in the analyses with the three PCR assays. Samples of animal origin contained PCR inhibitors. All seven undiluted animal samples were negative after analysis with the three PCR assays. However, more amplifications were possible after a 1:10 dilution. From seven samples, five $(71.4 \%)$ were positive with the LightCycler PCR assay and the concentrations were determined to be $8 \times 10^{3}$ calibrator CFU equivalents $\mathrm{ml}^{-1}$ and $7 \times 10^{7}$ calibrator CFU equivalents $\mathrm{ml}^{-1}$ in the two liquid manure samples and between 2 and 65 calibrator CFU equivalents $\mathrm{ml}^{-1}$ in the three positively tested slaughterhouse wastewater samples. The inhibition controls of the two samples that were negative after analysis with the LightCycler PCR assay were negative, indicating the presence of a strong PCR inhibitor in the samples. The same number of samples $(5 / 7,71.4 \%)$ was positive using the conventional PCR. With the TaqMan PCR assay, all seven samples from animal origin (liquid manure and slaughterhouse wastewater) were found to be negative. From the seven inhibition controls (samples spiked with $R$. coprophilus) five (71.4\%) were positive after analysis with the LightCycler PCR assay, four (57\%) with the TaqMan PCR assay and seven $(100 \%)$ with the conventional PCR assay.

Surface and spring water samples

As shown in Table 4, $R$. coprophilus could be amplified with the LightCycler PCR assay in five (16.7\%) out of 30 analysed surface water samples. The numbers calculated, ranged from $8 \times 10^{2}$ to $3 \times 10^{6}$ calibrator $\mathrm{CFU}$ equivalents $\mathrm{ml}^{-1}$ with a median value of $8.6 \times 10^{3}$. From 28 spring water samples, one positive result was obtained with a concentration of 715 calibrator CFU equivalents $\mathrm{ml}^{-1}$. All samples were negative when the conventional PCR assay or the TaqMan PCR assay was used for analysis.

\section{Discussion}

We developed a new LightCycler PCR assay detecting $R$. coprophilus, to overcome the drawbacks of detection methods used prior to this study. Compared with PCR assays that are available from the literature and with the culture-based method, the new molecular approach showed considerable advantages.

The design of a new PCR assay for detection of $R$. coprophilus is challenging. There are only nine nucleotide sequence entries available in the public databases, seven of them targeting the $16 \mathrm{~S}$ rRNA gene, one the gene for DNA gyrase $\mathrm{B}$ subunit and one the phthalate dioxygenase large
Table 3 Typical and atypical Rhodococcus coprophilus strains analysed with two real-time PCR assays

Data presented represent a single experiment

n.a. No amplification

\begin{tabular}{lllll}
\hline Strain identification & $\begin{array}{l}\text { LightCycler } \\
\text { Cq }\end{array}$ & $\begin{array}{l}\text { TaqMan } \\
\text { Cq }\end{array}$ & Classification & Highest similarity with sequence of \\
\hline RCK 36 & 13.10 & n.a. & Typical & R. coprophilus (X80626.1) \\
RCK 47b & 10.8 & n.a. & Typical & R. coprophilus (X80626.1) \\
RCK 53 & 14.7 & n.a. & Typical & $R$. coprophilus (X80626.1) \\
RCK 56 & 15.61 & n.a. & Typical & R. coprophilus (X80626.1) \\
RCK 57 & 13.25 & 16.99 & Typical & R. coprophilus (X80626.1) \\
RCK 66 & 16.87 & 19.69 & Typical & R. coprophilus (X80626.1) \\
RCK 69 & 18.19 & 19.62 & Typical & R. coprophilus (X80626.1) \\
RCK 54 & n.a. & 41.94 & Atypical & Dietzia sp. (DQ337507.1) \\
RCK 55 & n.a. & 39.14 & Atypical & Dietzia sp. (DQ337507.1) \\
RCK 67 & n.a. & 43.54 & Atypical & Dietzia sp. (AB376626.1) \\
RCK 68 & n.a. & 36.86 & Atypical & Dietzia sp. (DQ060380.1) \\
\hline
\end{tabular}


Table 4 Detection of Rhodococcus coprophilus after analysis of wastewater, surface and spring water samples with the three different PCR assays

\begin{tabular}{lcccc}
\hline Sample origin & No. of samples & \multicolumn{3}{l}{ Positive samples obtained with different PCR assays } \\
\cline { 3 - 5 } & & LightCycler PCR & TaqMan PCR & Conventional PCR \\
\hline Human $^{\mathrm{a}}$ & 10 & $1(10 \%)$ & $1(10 \%)$ & $2(20 \%)$ \\
Human $^{\mathrm{a}}$ inhibition control & 10 & $10(100 \%)$ & $10(100 \%)$ & $10(100 \%)$ \\
Animal $^{\mathrm{b}}$ & 7 & 0 & $2(28.6 \%)$ & 0 \\
Animal $^{\mathrm{b}}$ inhibition control & 7 & $1(14.3 \%)$ & 0 & $4(57.1 \%)$ \\
Animal $^{\mathrm{b}}$ 1:10 diluted & 7 & $5(71.4 \%)$ & $4(57 \%)$ & $5(71.4 \%)$ \\
Animal $^{\mathrm{b}}$ inhibition control 1: 10 diluted & 7 & $5(71.4 \%)$ & 0 & $7(100 \%)$ \\
Surface water $_{\text {Spring water }}$ & 30 & $5(16.7 \%)$ & 0 & 0 \\
\hline
\end{tabular}

${ }^{\text {a }}$ Samples from ten different wastewater treatment plants

${ }^{\mathrm{b}}$ Samples were obtained from two slaughterhouses and two farms

subunit gene (available at http://www.ncbi.nlm.nih.gov/ sites/entrez? $\mathrm{db}=$ nuccore $\& \mathrm{cmd}=$ search\&term $=$ Rhodococcus \%20coprophilus, accessed July 2010). From 13 different combinations of primers tested in this study, only the described primer pair (CL1.1 F and CL9R) was specific (no false positives) after combination with hybridisation probes. Using the primer pair for a conventional PCR is therefore not recommended. In general, the specificity should not be based on the probes of a PCR assay but on the primers, so as to avoid competitive reaction within the same PCR run. However, analysis of liquid manure, slaughterhouse wastewater and human wastewater suggested that the method is reliable for detecting $R$. coprophilus in environmental samples. Beside good general performance such as a low detection limit, repeatability and good efficiency of the new assay, some disadvantages have been observed. The transfer of the PCR assay to the LightCycler ${ }^{\circledR} 480$ instrument was not satisfactory because the fluorescence signals were low (data not shown). As shown in Tables 2-4, the new LightCycler PCR assay compared to the PCR assays previously described by Savill et al. (2001) had advantages including higher specificity and sensitivity, lower detection limit and better general performance. We conclude that the new primers and probe that have been used on the LightCyler detect a more representative set of target organisms. The detection limit of the conventional PCR assay obtained in this study was lower than in a previously published work that reported a value of $60 \mathrm{CFU} \mathrm{PCR}^{-1}$ (Savill et al. 2001). On the other hand, values for the detection limit of the TaqMan PCR assay were higher in our study when compared to the values described by Savill et al. (2001). Previous studies did not include any other strain for validation except for DSM 43347 (equal to ATCC 29080; Savill et al. 2001). In this study, higher detection limits were observed for other strains using the TaqMan PCR assay for analysis (Table 2).
Using the culture-based method on selective agar plates (Jagals et al. 1995; Mara and Oragui 1981; Oragui and Mara 1983), R. coprophilus was found in animal faeces and in water contaminated with animal faeces. In our study, slightly more bacteria were found in liquid manure than the numbers stated by Mara and Oragui (1981) from R. coprophilus 3.9 to $2.5 \times 10^{6} \mathrm{CFU} \mathrm{g}^{-1}$ in animal faecal specimens or the values obtained by Savill et al. (2001) from $3.3 \times 10^{5}$ to $3.6 \times 10^{6} \mathrm{CFU} \mathrm{g}^{-1}$ in cow faeces. The abundance of $R$. coprophilus in surface water was similar to values found previously with the range of $1 \times 10^{2}$ to $1 \times 10^{6} \mathrm{CFU}^{-1}$ (extrapolated value; Long et al. 2003). In comparison with the time-consuming culture-based method, the LightCycler PCR assay showed several advantages. Using the culturebased method only $20 \%$ of presumptive colonies were $R$. coprophilus. Therefore, we conclude that confirmation of presumptive colonies on TSA or with a PCR assay was necessary in order to distinguish typical from atypical isolates. The subculture increased the specificity of the culturebased method although resulted in an even more timeconsuming procedure. In contrast, detecting $R$. coprophilus with the culture-independent molecular approach is easy, rapid and reliable.

Beside R. coprophilus, Streptococcus bovis (Mara and Oragui 1981; Oragui and Mara 1983), thermophilic bifidobacteria (Gavini et al. 1991), F-RNA phage subgroup I (Havelaar et al. 1990) and different molecular methods targeting the phylum bacteroidetes (Layton et al. 2006; Reischer et al. 2006; Shanks et al. 2006, 2008, 2010) were described to indicate animal contamination. We selected $R$. coprophilus as the indicator of animal faecal pollution based on its high abundance in environmental water including watersheds from which raw drinking water was obtained (Long et al. 2003; Mara and Oragui 1981; Oragui and Mara 1983). The goal was to establish and validate a reliable method to investigate the occurrence of $R$. coprophilus in 
environmental water samples including spring water. Our work demonstrated that the method, with a low detection limit, can be applied for that purpose and that the method is sufficiently sensitive and robust to detect $R$. coprophilus in spring water. However, the number $(16.7 \%)$ of positive surface water samples was rather small and might be increased by testing larger sample volumes of water. Sinton et al. (1998) described the long-term survival of $R$. coprophilus in environmental waters and therefore concluded that the organism cannot be used to give an indication of recent pollution. For an application of the method for analysis of spring water, the long persistence of the target microorganism in water may be beneficial and because bacteria from both remote and recent pollution are present contributes to the higher probability of detecting this organism. Although it is important to be aware that results cannot give any indication on the specific time of faecal pollution, they are useful to determine animal-derived faecal contamination.

In conclusion, the present study improves the analysis of $R$. coprophilus in wastewater, surface and spring water. Compared with all assays that are available in the literature, the new molecular approach showed advantages such as improved sensitivity and specificity and a much lower detection limit. Consequently, there is evidence to suggest that the new molecular approach is a useful tool to identify animal sources of faecal pollution in water. However, larger volumes of environmental water samples should be analysed to further validate and improve the method in respect of the amount of positive water samples.

Acknowledgements The present study was conducted in the laboratories of the Consumer Protection Directorate of the Federal Office of Public Health (FOPH; 3003 Bern, Switzerland) and was financed by research grant FOPH/07.006623. The authors would like to thank Dr. Dominik Moor (FOPH) for proofreading the article.

\section{References}

Anon (2006) Swiss Accreditation Service: Leitfaden zur Validierung mikrobiologischer Prüfverfahren und zur Abschätzung der Messunsicherheit im Bereich Lebensmittel- und Umweltmikrobiologie. Mitt Lebensm Hyg 97:73-106

Bustin SA, Benes V, Garson JA, Hellemans J, Huggett J, Kubista M, Mueller R, Nolan T, Pfaffl MW, Shipley GL, Vandesompele J, Wittwer CT (2009) The MIQE guidelines: minimum information for publication of quantitative real-time PCR experiments. Clin Chem 55:611-622

Gavini F, Pourcher AM, Neut C, Monget D, Romond C, Oger C, Izard D (1991) Phenotypic differentiation of bifidobacteria of human and animal origins. Int J Syst Bacteriol 41:548-557

Havelaar AH, Pot-Hogeboom WM, Furuse K, Pot R, Hormann MP (1990) F-specific RNA bacteriophages and sensitive host strains in faeces and wastewater of human and animal origin. J Appl Bacteriol 69:30-37
Jagals P, Grabow WOK, de Villiers JC (1995) Evaluation of indicators for assessment of human and animal faecal pollution of surface run-off. Water Sci Technol 31:235-241

Layton A, McKay L, Williams D, Garrett V, Gentry R, Sayler G (2006) Development of Bacteroides 16S rRNA gene TaqMan-based realtime PCR assays for estimation of total, human, and bovine fecal pollution in water. Appl Environ Microbiol 72:4214-4224

Long SC, Shafer E, Arango C, Siraco D (2003) Evaluation of three source tracking indicator organisms for watershed management. J Water SRT Aqua 52:565-575

Mara DD, Oragui JI (1981) Occurrence of Rhodococcus coprophilus and associated actinomycetes in feces, sewage, and freshwater. Appl Environ Microbiol 42:1037-1042

Mara DD, Oragui JI (1983) Sorbitol-fermenting bifidobacteria as specific indicators of human faecal pollution. J Appl Bacteriol 55:349-357

Meays CL, Broersma K, Nordin R, Mazumder A (2004) Source tracking fecal bacteria in water: a critical review of current methods. J Environ Manage 73:71-79

Mendez J, Audicana A, Isern A, Llaneza J, Moreno B, Tarancon ML, Jofre J, Lucena F (2004) Standardised evaluation of the performance of a simple membrane filtration-elution method to concentrate bacteriophages from drinking water. J Virol Methods 117:19 25

Oragui JI, Mara DD (1983) Investigation of the survival characteristics of Rhodococcus coprophilus and certain fecal indicator bacteria. Appl Environ Microbiol 46:356-360

Reischer GH, Kasper DC, Steinborn R, Mach RL, Farnleitner AH (2006) Quantitative PCR method for sensitive detection of ruminant fecal pollution in freshwater and evaluation of this method in alpine karstic regions. Appl Environ Microbiol 72:5610-5614

Rowbotham TJ, Cross T (1977a) Ecology of Rhodococcus coprophilus and associated actionomycetes in fresh water and agricultural habitats. J Gen Microbiol 100:231-240

Rowbotham TJ, Cross T (1977b) Rhodococcus coprophilus sp. nov.:an aerobic nocardioform actinomycete belonging to the 'rhodochrous' complex. J Gen Microbiol 100:123-138

Savichtcheva O, Okabe S (2006) Alternative indicators of fecal pollution: relations with pathogens and conventional indicators, current methodologies for direct pathogen monitoring and future application perspectives. Water Res 40:2463-2476

Savill MG, Murray SR, Scholes P, Maas EW, McCormick RE, Moore EB, Gilpin BJ (2001) Application of polymerase chain reaction (PCR) and TaqMan PCR techniques to the detection and identification of Rhodococcus coprophilus in faecal samples. J Microbiol Methods 47:355-368

Scott TM, Rose JB, Jenkins TM, Farrah SR, Lukasik J (2002) Microbial source tracking: current methodology and future directions. Appl Environ Microbiol 68:5796-5803

Shanks OC, Santo Domingo JW, Lamendella R, Kelty CA, Graham JE (2006) Competitive metagenomic DNA hybridization identifies host-specific microbial genetic markers in cow fecal samples. Appl Environ Microbiol 72:4054-4060

Shanks OC, Atikovic E, Blackwood AD, Lu J, Noble RT, Domingo JS, Seifring S, Sivaganesan M, Haugland RA (2008) Quantitative PCR for detection and enumeration of genetic markers of bovine fecal pollution. Appl Environ Microbiol 74:745-752

Shanks OC, White K, Kelty CA, Hayes S, Sivaganesan M, Jenkins M, Varma M, Haugland RA (2010) Performance assessment PCR-based assays targeting bacteroidales genetic markers of bovine fecal pollution. Appl Environ Microbiol 76:1359 1366

Sinton LW, Finlay RK, Hannah DJ (1998) Distinguishing human from animal faecal contamination in water: a review. $\mathrm{N}$ Z J Mar Freshwater Res 32:323-348 